Article

\title{
Nonprenylated Xanthones from Gentiana lutea, Frasera caroliniensis, and Centaurium erythraea as Novel Inhibitors of Vascular Smooth Muscle Cell Proliferation
}

\author{
Birgit Waltenberger ${ }^{1, \dagger}$, Rongxia Liu ${ }^{2,3, \dagger}$, Atanas G. Atanasov ${ }^{2, *}$, Stefan Schwaiger ${ }^{1}$, \\ Elke H. Heiss ${ }^{2}$, Verena M. Dirsch ${ }^{2}$ and Hermann Stuppner ${ }^{1, *}$ \\ Received: 30 September 2015 ; Accepted: 3 November 2015 ; Published: 13 November 2015 \\ Academic Editor: Pascal Richomme \\ 1 Institute of Pharmacy/Pharmacognosy, University of Innsbruck, 6020 Innsbruck, Austria; \\ birgit.waltenberger@uibk.ac.at (B.W.); stefan.schwaiger@uibk.ac.at (S.S.) \\ 2 Department of Pharmacognosy, University of Vienna, 1090 Vienna, Austria; \\ liurongxia107@outlook.com (R.L.); elke.heiss@univie.ac.at (E.H.H.); verena.dirsch@univie.ac.at (V.M.D.) \\ 3 School of Pharmacy, Yantai University, 264005 Yantai, China \\ * Correspondence: atanas.atanasov@univie.ac.at (A.G.A.); hermann.stuppner@uibk.ac.at (H.S.); \\ Tel.: +43-1-4277-55231 (A.G.A.); +43-512-507-58400 (H.S.); \\ Fax: +43-1-4277-55969 (A.G.A.); +43-512-507-58499 (H.S.) \\ $\dagger \quad$ These authors contributed equally to this work.
}

\begin{abstract}
Aberrant proliferation of vascular smooth muscle cells (VSMC) plays a major role in restenosis, the pathological renarrowing of the blood vessel lumen after surgical treatment of stenosis. Since available anti-proliferative pharmaceuticals produce unfavorable side effects, there is high demand for the identification of novel VSMC proliferation inhibitors. A natural product screening approach using a resazurin conversion assay enabled the identification of gentisin (1) from Gentiana lutea as a novel inhibitor of VSMC proliferation with an $\mathrm{IC}_{50}$ value of $7.84 \mu \mathrm{M}$. Aiming to identify further anti-proliferative compounds, 13 additional nonprenylated xanthones, isolated from different plant species, were also tested. While some compounds showed no or moderate activity at $30 \mu \mathrm{M}, 1$-hydroxy-2,3,4,5-tetramethoxyxanthone (4), swerchirin (6), and methylswertianin (7) showed $\mathrm{IC}_{50}$ values between 10.2 and $12.5 \mu \mathrm{M}$. The anti-proliferative effect of $\mathbf{1}, \mathbf{4}, \mathbf{6}$, and $\mathbf{7}$ was confirmed by the quantification of DNA synthesis (BrdU incorporation) in VSMC. Cell death quantification (determined by LDH release in the culture medium) revealed that the compounds are not cytotoxic in the investigated concentration range. In conclusion, nonprenylated xanthones are identified as novel, non-toxic VSMC proliferation inhibitors, which might contribute to the development of new therapeutic applications to combat restenosis.
\end{abstract}

Keywords: atherosclerosis; bitter plants; Centaurium erythraea; Frasera caroliniensis; Gentiana lutea; Gentianaceae; gentisin; restenosis; vascular smooth muscle cell proliferation; xanthones

\section{Introduction}

Coronary artery disease is a major cause of death worldwide. It is primarily caused by atherosclerosis, a complex process that involves inflammation, deposition of lipids, smooth muscle cell proliferation, and plaque formation. This results in stenosis, the abnormal narrowing of a blood vessel caused by thickening of the arterial wall, and leads to insufficient blood flow [1]. To counteract this obstruction, surgical interventions are performed. However, a common adverse event of such 
surgical treatment is restenosis, the pathological recurrence of blood vessel constriction. This process is strongly associated with the excessive proliferation of vascular smooth muscle cells (VSMC) [2].

Anti-proliferate compounds, e.g., paclitaxel (taxol) and rapamycin, are used in drug-eluting stents, in order to overcome restenosis by inhibition of VSMC growth. Unfortunately, these substances produce unfavorable side effects such as impaired reendothelialization and thrombosis induction [3]. Therefore, due to the side effect profiles of available pharmaceuticals, there is great interest in the discovery of new VSMC proliferation inhibitors [2].

Plant-derived natural products are evolutionarily privileged structures which provide structural complexity and affinity for biological targets [4]. They represent an excellent basis for the search for novel biologically active compounds and the development of new therapeutic drugs [5].

The aim of our study was to find novel natural product inhibitors of VSMC proliferation. Therefore, we tested in-house available natural products using a resazurin conversion assay to assess their potential to inhibit VSMC proliferation. This approach led to the identification of a xanthone derivative from Gentiana lutea as a novel VSMC proliferation inhibitor. Further compounds with similar chemical structures, isolated from different plant species of the Gentianaceae family, were additionally selected for testing of their anti-proliferative activity. Measurement of DNA synthesis in VSMC by quantification of 5-bromo-2'-deoxyuridine (BrdU) incorporation into DNA was used to confirm the anti-proliferative effect of the most promising compounds. Cell death quantification (based on lactate dehydrogenase (LDH) release in the culture medium) was utilized to assess potential toxicity.

\section{Results and Discussion}

With the aim to identify novel natural product inhibitors of VSMC proliferation, we tested several natural products (not shown) from our in-house compound collection on their ability to inhibit proliferation of rat aortic VSMC induced by the platelet-derived growth factor (PDGF), which is a mitogen strongly associated with aberrant proliferation in restenosis [6] and leads to excessive proliferation of VSMC. After stimulation of the VSMC for $48 \mathrm{~h}$ with PDGF, the total number of metabolically active cells was measured by resazurin conversion. In this way, the xanthone gentisin (1,7-dihydroxy-3-methoxyxanthone (1) [7]), previously isolated from the root material of G. lutea [8], a well-known medicinal bitter plant from the Gentianaceae family, was identified as a novel inhibitor of VSMC proliferation. At a concentration of $30 \mu \mathrm{M}$, the compound completely inhibited PDGF-induced proliferation to the basal level (Figure 1A). Although an anti-proliferative effect of a prenylated xanthone has been described earlier [9], it represents a novel activity for simple, nonprenylated xanthones.

To identify further active compounds and to possibly gain knowledge about the structure activity relationship (SAR), further xanthone derivatives with structural similarity to 1, derived from different bitter plants from the Gentianaceae family, were additionally selected for biological testing. Figure 2 depicts compound 1 as well as the additionally selected xanthones.

Isogentisin (1,3-dihydroxy-7-methoxyxanthone (2) [7]), the isomer of compound 1, also previously isolated from yellow gentian root material in the same phytochemical approach [8], was one of the additionally selected analogs. Both compounds are xanthones with a simple 1,3,7-oxygenation pattern and one methoxy substituent. They differ only in the position of the methoxy substituent, which is in position 3 in $\mathbf{1}$ and in position 7 in compound $\mathbf{2}$.

In addition, four xanthones (1-hydroxy-2,3,5-trimethoxyxanthone (3) [10], 1-hydroxy-2,3,4,5tetramethoxyxanthone (4) [11], 1-hydroxy-2,3,4,7-tetramethoxyxanthone (5) [11], and 1,8-dihydroxy3,5-dimethoxyxanthone (swerchirin) (6) [12]), previously derived from the roots of Frasera caroliniensis [13], also called American columbo, another bitter plant from the Gentianaceae family, were also selected for biological testing. These compounds also comprise the same structural skeleton like compound $\mathbf{1}$, but with a slightly different substitution pattern. While $\mathbf{1}$ and $\mathbf{2}$ are trisubstituted xanthones, the compounds selected from $F$. caroliniensis possess a higher oxidation level. Compounds 
$\mathbf{3}$ and $\mathbf{6}$ are tetraoxygenated, whereby compounds $\mathbf{4}$ and $\mathbf{5}$ are pentaoxygenated xanthones. With the exception of $\mathbf{6}$, which comprises two hydroxy groups, these compounds bear one hydroxy substituent. All other substituents are methoxy groups. In addition to the higher number of methoxy groups and total substituents, these compounds also differ in the position of the substituents.

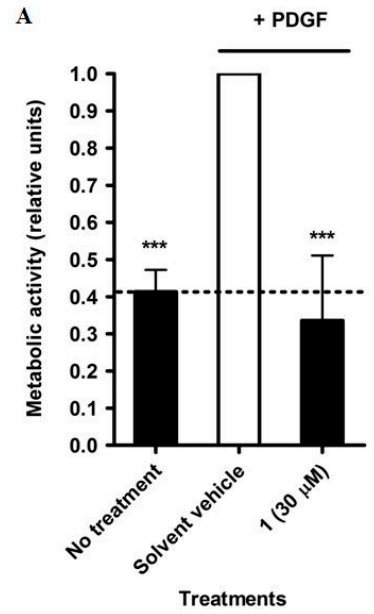

B

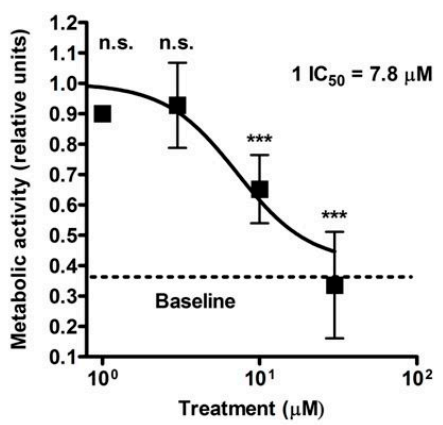

Figure 1. Inhibition of VSMC proliferation by gentisin (1), determined by the resazurin conversion method. Cells were treated with the indicated concentrations of 1 for $48 \mathrm{~h}$. (A) represents the data obtained from VSMC treated or untreated with PDGF, as well as the inhibitory effect of $30 \mu \mathrm{M} 1$ on PDGF-induced VSMC proliferation; (B) depicts the results obtained from dose response studies (investigated concentrations: $1,3,10$, and $30 \mu \mathrm{M}$ ) used to determine the $\mathrm{IC}_{50}$ of $\mathbf{1}$. Values are presented as means $\pm \mathrm{SD}$, relative to the PDGF stimulated solvent vehicle control $(0.1 \% \mathrm{DMSO})(n=3)$. *** $p<0.001$, n.s. not significant (ANOVA/Bonferroni).
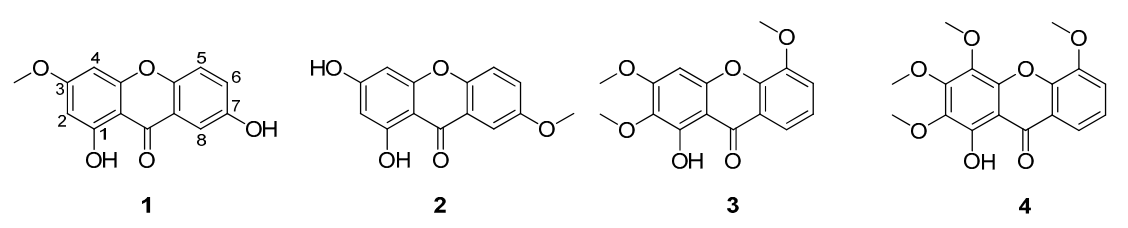<smiles>COc1ccc2oc3c(OC)c(OC)c(OC)c(O)c3c(=O)c2c1</smiles><smiles>COC1=COc2ccc(O)c(O)c(=O)c2C(O)=C1</smiles><smiles>COc1cc(O)c2c(=O)c3c(O)c(OC)ccc3oc2c1</smiles><smiles>COc1cc(O)c2c(=O)c3cccc(O)c3oc2c1</smiles><smiles>COc1cc(O)c2c(=O)c3c(O)ccc(O)c3oc2c1</smiles><smiles>COc1cc(O)c2c(=O)c3ccc(O)c(OC)c3oc2c1</smiles><smiles>COC1=C(O)c2c(ccc(O)c2OC)C(=O)C1=O</smiles><smiles>COc1cc(O)c2c(=O)c3c(OC)c(OC)c(O)c(OC)c3oc2c1</smiles><smiles>COc1cc(O)c2c(=O)c3c(O)c(OC)c(O)c(OC)c3oc2c1</smiles><smiles>COc1c(O)cc2oc3c(O)cccc3c(=O)c2c1O</smiles>

Figure 2. Chemical structures of xanthones 1-14. 
Moreover, eight xanthone derivatives (1,8-dihydroxy-3,7-dimethoxyxanthone (methylswertianin) (7) [12], 1,5-dihydroxy-3-methoxyxanthone (mesuaxanthone A) (8) [14], 1,5,8-trihydroxy-3-methoxyxanthone (bellidifolin) (9) [15], 1,6-dihydroxy-3,5-dimethoxyxanthone (10) [16,17], 1,3,6-trihydroxy-2,5-dimethoxyxanthone (11) [18], 1,6-dihydroxy-3,5,7,8tetramethoxyxanthone (12) [16,19], 1,6,8-trihydroxy-3,5,7-trimethoxyxanthone (13) [16], and 1,3,5-trihydroxy-2-methoxyxanthone (tovopyrifolin C) (14) [20], Figure 2) previously isolated from the aerial parts of Centaurium erythraea [13], well known as small centaury, were also selected for biological testing. Compound 6, isolated from F. caroliniensis, is also present in C. erythraea [13]. These xanthone derivatives are structurally similar to compound 1, but with a slightly different substitution pattern. They bear three to six substituents, all hydroxy or methoxy groups, in various positions.

Whereas some of these 13 additional xanthones showed no or only weak activity at a concentration of $30 \mu \mathrm{M}$, five of them (i.e., 2, 4, 6, 7, and 8) inhibited PDGF-stimulated proliferation of VSMC with residual activity values of less than 0.75 relative units (RU) at a concentration of $30 \mu \mathrm{M}$ (Table 1). These five compounds, together with 1, which reduced VSMC proliferation to 0.34 RU at $30 \mu \mathrm{M}$, were thus analyzed in more detail in concentration response studies using the resazurin conversion assay. All six compounds inhibited VSMC proliferation in a concentration-dependent manner. Compounds 4, 6, and 7 showed $\mathrm{IC}_{50}$ values of $11.2,12.5$, and $10.2 \mu \mathrm{M}$, while 2 and 8 were less active in this test system with $\mathrm{IC}_{50}$ values of 27.0 and $29.5 \mu \mathrm{M}$, respectively (Table 1). Gentisin (1) was the most active compound. It exhibited a concentration-dependent inhibition of VSMC proliferation with an $\mathrm{IC}_{50}$ value of $7.84 \mu \mathrm{M}$ (Figure 1B). For comparison, we have also determined the effect of the clinically used VSMC proliferation inhibitor taxol, which displayed an $\mathrm{IC}_{50}$ value of $0.1 \mu \mathrm{M}$ [21].

Table 1. Inhibition of VSMC proliferation by compounds 1-14 in the resazurin conversion and in the BrdU incorporation assays. Data (means $\pm \mathrm{SD}, n=3$ ) are presented as relative units (RU) in comparison to the control (cells treated with PDGF in the presence of $0.1 \%$ DMSO vehicle; $1.00 \mathrm{RU}$ ) or $\mathrm{IC}_{50}$ values.

\begin{tabular}{|c|c|c|c|c|}
\hline \multirow[b]{3}{*}{$\begin{array}{l}\text { Compound } \\
\text { Number }\end{array}$} & \multirow[b]{3}{*}{ Compound Name } & \multicolumn{3}{|c|}{ Inhibition of VSMC Proliferation } \\
\hline & & \multicolumn{2}{|c|}{ Resazurin Conversion Assay } & \multirow{2}{*}{$\begin{array}{l}\text { BrdU Assay } \\
\mathrm{IC}_{50}(\mu \mathrm{M})\end{array}$} \\
\hline & & $\begin{array}{l}\quad \text { at } 30 \mu \mathrm{M} \\
\text { (Relative to Solvent } \\
\text { vehicle }=1.00, \mathrm{RU})\end{array}$ & $\begin{array}{l}\text { IC }_{50} \\
(\mu \mathrm{M})\end{array}$ & \\
\hline 1 & 1,7-diOH-3-MeO-xanthone (gentisin) ${ }^{a}$ & $0.335 \pm 0.175$ & 7.84 & 5.74 \\
\hline 2 & 1,3-diOH-7-MeO-xanthone (isogentisin) ${ }^{\mathrm{a}}$ & $0.593 \pm 0.084$ & 27.0 & n.d. ${ }^{\mathrm{d}}$ \\
\hline 3 & 1-OH-2,3,5-triMeO-xanthone ${ }^{b}$ & $0.832 \pm 0.104$ & n.d. & n.d. \\
\hline 4 & 1-OH-2,3,4,5-tetraMeO-xanthone ${ }^{b}$ & $0.216 \pm 0.058$ & 11.2 & 24.5 \\
\hline 5 & 1-OH-2,3,4,7-tetraMeO-xanthone ${ }^{b}$ & $0.754 \pm 0.014$ & n.d. & n.d. \\
\hline 6 & 1,8-diOH-3,5-diMeO-xanthone (swerchirin) ${ }^{b, c}$ & $0.514 \pm 0.067$ & 12.5 & 7.37 \\
\hline 7 & 1,8-diOH-3,7-diMeO-xanthone (methylswertianin) ${ }^{c}$ & $0.002 \pm 0.014$ & 10.2 & 7.53 \\
\hline 8 & 1,5-diOH-3-MeO-xanthone (mesuaxanthone A) ${ }^{c}$ & $0.713 \pm 0.061$ & 29.5 & n.d. \\
\hline 9 & 1,5,8-triOH-3-MeO-xanthone (bellidifolin) ${ }^{c}$ & $0.783 \pm 0.031$ & n.d. & n.d. \\
\hline 10 & 1,6-diOH-3,5-diMeO-xanthone ${ }^{c}$ & $0.987 \pm 0.025$ & n.d. & n.d. \\
\hline 11 & 1,3,6-triOH-2,5-diMeO-xanthone ${ }^{c}$ & $0.942 \pm 0.042$ & n.d. & n.d. \\
\hline 12 & 1,6-diOH-3,5,7,8-tetraMeO-xanthone ${ }^{c}$ & $0.862 \pm 0.068$ & n.d. & n.d. \\
\hline 13 & 1,6,8-triOH-3,5,7-triMeO-xanthone ${ }^{c}$ & $0.846 \pm 0.096$ & n.d. & n.d. \\
\hline 14 & 1,3,5-triOH-2-MeO-xanthone (tovopyrifolin C) ${ }^{\mathrm{c}}$ & $0.862 \pm 0.104$ & n.d. & n.d. \\
\hline
\end{tabular}

Since the resazurin conversion assay is based on the ability of viable cells to transform resazurin into the fluorescent compound resorufin, there is a good correlation between the measured fluorescence and the number of living cells. However, in this model, substances might modulate the cellular metabolic capacity or directly interfere with the redox-dependent resazurin to resorufin conversion, thus leading to false activity estimation.

Thus, in order to confirm the anti-proliferative activity of the four most active xanthones 1, 4, 6, and 7 , which exhibited $\mathrm{IC}_{50}$ values between 7.84 and $12.5 \mu \mathrm{M}$ in the resazurin conversion assay, they were additionally investigated using the BrdU incorporation assay. In this assay, the DNA synthesis 
in dividing VSMC is measured by quantification of BrdU incorporation into newly synthesized DNA. All four compounds showed activity in a similar range as in the resazurine model. Moreover, in all four cases, higher compound concentration led to stronger inhibition of VSMC proliferation. Thus, a concentration-dependent inhibition was observed. In particular, compounds 1, 4, 6, and 7 inhibited DNA synthesis with $\mathrm{IC}_{50}$ values of 5.74, 24.5, 7.37, and $7.53 \mu \mathrm{M}$, respectively (Figure 3, Table 1). For comparison, we have also determined the effect of the cyclin-dependent kinase (CDK) inhibitor roscovitine, which displayed an $\mathrm{IC}_{50}$ value of $16.9 \mu \mathrm{M}$ [22].

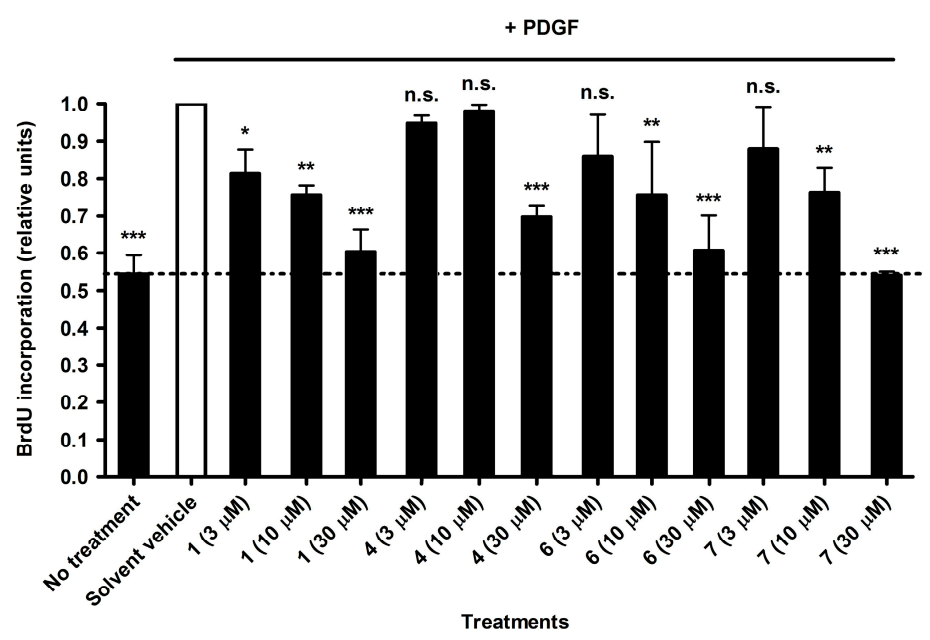

Figure 3. Inhibition of VSMC proliferation by compounds 1, 4, 6, and 7 measured with the BrdU assay. Values are presented as means $\pm \mathrm{SD}$, relative to the PDGF stimulated solvent vehicle control $\left(0.1 \%\right.$ DMSO) $(n=3) .{ }^{* * *} p<0.001,{ }^{* *} p<0.01,{ }^{*} p<0.05$, n.s. not significant (ANOVA/Bonferroni).

To ensure that the observed inhibitory effect on VSMC proliferation is not due to cytotoxicity, the four most active compounds were additionally analyzed for potential cytotoxic effects. Loss of VSMC membrane integrity as a sign for cell death was quantified by measuring the release of the soluble cytosolic protein LDH. This assay revealed that the compounds are not cytotoxic in the investigated concentration range up to $30 \mu \mathrm{M}$ (Figure 4).

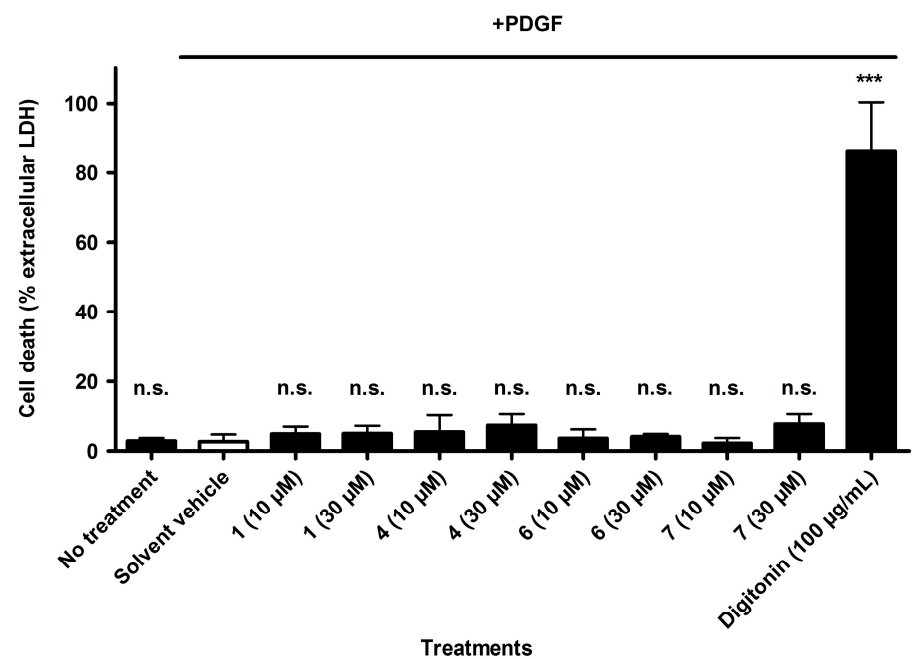

Figure 4. Determination of potential cytotoxic effects of compounds 1, 4, 6, and 7. Digitonin (100 $\mu \mathrm{g} / \mathrm{mL}$, corresponding to $81 \mu \mathrm{M})$ was used as positive control, vehicle $(0.1 \% \mathrm{DMSO})$ with and without PDGF was used as negative control. Values are presented as means $\pm \operatorname{SD}(n=3) .{ }^{* * *} p<0.001$, n.s. not significant (ANOVA/Bonferroni). 
While an anti-proliferative effect of cudratricusxanthone A, an isoprenylated xanthone from the root bark of Cudrania tricuspidata, was described by Kim et al. [9], this is the first report of nonprenylated xanthones as inhibitors of VSMC proliferation.

In the present study, 14 xanthone derivatives were investigated on their anti-proliferative effects in rat aortic VSMC. Although they are structurally closely related, they demonstrated very different activities. Gentisin (1) turned out to be the most potent compound, but also 4, 6, and 7 showed potent inhibitory activity, whereas 2 and 8 were moderately active and compounds 3, 5, and 9-14 were weakly active or inactive. However, based on these data, no clear conclusions about the SAR of these compounds could be drawn, since there is no clear relation between the activity of the xanthones and their substitution pattern. Therefore, further studies including the investigation of additional xanthone derivatives are necessary to gain better knowledge about the SAR of simple, oxygenated xanthones. Moreover, VSMC proliferation is a complex phenotypic effect that may be a result of various interactions between a small molecule and regulatory proteins whereby the modification of a small molecule might enhance interaction with one relevant protein but simultaneously weaken the interaction with other relevant protein(s). Therefore, the lack of a clear SAR in this study might also be due to a complex mechanism of action. Thus, to reveal a clear SAR, more detailed studies on the molecular mechanism of action of the xanthones are required.

The four most active xanthones are constituents of G. lutea (compound 1), F. caroliniensis (compounds 4 and 6), and C. erythraea (compounds 6 and 7). However, the most potent xanthone derivative 1, gentisin, was derived from G. lutea, together with its moderately active isomer 2. Therefore, in order to determine whether the anti-proliferative activity of these compounds affects the activity of the crude extract, we additionally investigated the crude methanol extract of $G$. lutea roots [8], from which the compounds were previously isolated and which had been stored at $-80{ }^{\circ} \mathrm{C}$. The extract was tested in the resazurin conversion assay at a concentration of $30 \mu \mathrm{g} / \mathrm{mL}$, but with inhibition of VSMC proliferation to $0.846 \pm 0.020 \mathrm{RU}$, the observed anti-proliferative activity was only weak. In a previous work [23] we have determined the phytochemical profile of the G. lutea root methanol extract and quantified the main constituents in extracts of several commercially available G. lutea samples. The most dominant compound with a concentration of up to $9.53 \%$ was the bitter tasting secoiridoid glycoside gentiopicroside, followed by loganic acid, swertiamarin, and the glycosides of $\mathbf{1}$ and $\mathbf{2}$. The aglycones $\mathbf{1}$ and $\mathbf{2}$ were present in much lower concentrations. While the concentration of the moderately active 2 was determined to be $0.04 \%-0.11 \%$, the most active compound 1 was present in a concentration of only $0.02 \%-0.07 \%$. The low concentration of the active compounds is likely the reason for the weak anti-proliferative activity of the crude extract.

Kesavan et al. [24] reported the inhibition of PDGF induced proliferation of rat aortic smooth muscle cells by a water extract of $G$. lutea roots, however, at a much higher concentration $(1 \mathrm{mg} / \mathrm{mL})$. Furthermore, they identified the flavonoid isovitexin as an inhibitor of VSMC proliferation. Akileshwari et al. [25] suggested the presence of this compound in methanol and water extracts of G. lutea roots due to the monitored $m / z$ of $433.8520[\mathrm{M}+\mathrm{H}]^{+}$in a MALDI-TOF analysis. This is not in accordance with a study by Kusar et al. [26], who investigated the extraction of isovitexin, among other compounds, from yellow gentian leaves and roots using methanol, ethanol, and/or water as extraction solvents. While isovitexin was present in the leaf extracts, it could not be detected by HPLC-UV in comparison with reference compounds in any of the root extracts. This is in agreement with our results. We could also not detect isovitexin in our methanolic G. lutea root extract, while the xanthones 1 and 2 were present in minor amounts.

However, the results show that the bioactivity-guided approach often followed is not always the best choice. An extract possessing only weak activity is usually not investigated further. In this case, starting with crude extracts and only continuing with highly potent extracts would have led to the missing out of an interesting bioactivity. Instead, direct investigation of isolated natural products as an alternative approach led to the identification of novel inhibitors of VSMC proliferation. Especially for applications for which extracts cannot be considered due to their overly complex composition, as 
is the case for a potential topical application in a stent, direct testing of isolated natural products, enabling the quick identification of pure compounds as active agents, is meaningful. Moreover, the bioactivity of compounds that are present only in trace quantities in plant extracts, can also be identified in this way.

In this study, using a direct testing of natural products strategy, we identified gentisin (1) as a novel inhibitor of VSMC proliferation. Pharmacological investigation of additional xanthones with related chemical structures led to the identification of further active compounds. The activity of the most potent compounds was confirmed by inhibition of VSMC proliferation in a BrdU assay and it was shown that the compounds are not cytotoxic. Another advantage of these compounds is their high chemical stability, which could be a benefit in the manufacturing process. Stability studies conducted according to the ICH-guidelines (www.ich.org) revealed that they are stable under long-term, accelerated, and refrigerated conditions [13].

\section{Experimental Section}

\subsection{Chemicals and Reagents}

Growth media, serum, and cell culture supplements were purchased from Lonza (Braine-L'Alleud, Belgium). The chemoluminescent BrdU cell proliferation kit was obtained from Roche Diagnostics (Vienna, Austria). All other reagents used were of analytical grade and obtained from Sigma-Aldrich (Vienna, Austria).

\subsection{Cell Culture}

Rat aortic VSMC were acquired from Lonza and grown in Dulbecco's modified essential medium (DMEM)-F12 (1:1) supplemented with 20\% fetal calf serum (FCS) and gentamycin. For all experiments, cells were seeded in 96-well plates $\left(5 \times 10^{3}\right.$ cells/well) and incubated for $24 \mathrm{~h}$. Subsequently, cells were serum-starved for another $24 \mathrm{~h}$ to make them quiescent.

\subsection{Resazurin Conversion Assay}

Quiescent VSMC were pre-treated with the studied test compounds, G. lutea root extract, or vehicle $(0.1 \% \mathrm{DMSO})$ for $30 \mathrm{~min}$ and then stimulated with PDGF-BB $(20 \mathrm{ng} / \mathrm{mL})$ for $48 \mathrm{~h}$. The number of metabolically active VSMC was measured by resazurin conversion $[27,28]$. Therefore, after washing the cells with phosphate-buffered saline (PBS), they were incubated in serum-free medium containing resazurin $(10 \mu \mathrm{g} / \mathrm{mL})$ for $2 \mathrm{~h}$. Measurement of total metabolic activity was performed by monitoring the increase in fluorescence at $590 \mathrm{~nm}$ using an excitation wavelength of $535 \mathrm{~nm}$ in a 96-well plate reader (Tecan GENios Pro, Grödig, Austria). The assay was validated using the VSMC proliferation inhibitor taxol $\left(\mathrm{IC}_{50}=0.1 \mu \mathrm{M}[21]\right)$.

\subsection{5-Bromo-2'-deoxyuridine (BrdU) Incorporation Assay}

Quiescent VSMC were pre-treated with test compounds or vehicle (0.1\% DMSO) for 30 min and then stimulated with PDGF-BB $(20 \mathrm{ng} / \mathrm{mL})$ for $2 \mathrm{~h}$. Subsequently, BrdU was added to estimate de novo DNA synthesis in VSMC $[29,30]$. After $22 \mathrm{~h}$, the BrdU incorporation was determined according to the instructions of the manufacturer (Roche Diagnostics, Vienna, Austria). The assay was validated using the $\mathrm{CDK}$ inhibitor roscovitine $\left(\mathrm{IC}_{50}=16.9 \mu \mathrm{M}[22]\right)$.

\subsection{Assessment of Cytotoxicity}

Quiescent VSMC were pre-treated with test compounds, positive control (digitonin $100 \mu \mathrm{g} / \mathrm{mL}$, corresponding to $81 \mu \mathrm{M})$, or vehicle $(0.1 \% \mathrm{DMSO})$ for $30 \mathrm{~min}$ and then stimulated with PDGF-BB $(20 \mathrm{ng} / \mathrm{mL}$ ) for $24 \mathrm{~h}$. Loss of cell membrane integrity as an indicator for cell death was quantified by measuring the release of $\mathrm{LDH}[31,32]$. Therefore, the LDH activity of the cell supernatant was determined. To estimate total $\mathrm{LDH}$, identically treated samples were incubated in the presence of $1 \%$ 
Triton X-100 for $45 \mathrm{~min}$. The activity of released and total LDH enzyme activity was measured for $30 \mathrm{~min}$ in the dark in presence of lactate $(4.5 \mathrm{mg} / \mathrm{mL}), \mathrm{NAD}^{+}(0.56 \mathrm{mg} / \mathrm{mL})$, diaphorase $(1.69 \mathrm{U} / \mathrm{mL})$, $0.004 \%(w / v)$ BSA, $0.15 \%(w / v)$ sucrose, and $0.5 \mathrm{mM}$ 2-p-iodophenyl-3-nitrophenyl tetrazolium chloride (INT). The enzyme reaction was stopped by oxymate $(1.78 \mathrm{mg} / \mathrm{mL})$ and the absorbance was read at $490 \mathrm{~nm}$. The percentage of extracellular LDH enzyme activity was calculated to estimate potential effects of the samples on cell viability.

\subsection{Statistical Analysis}

Statistical analysis was conducted by ANOVA/Bonferroni test using the software GraphPad PRISM, version 4.03 (GraphPad Software, La Jolla, CA, USA). The number of experiments is provided in the figure legends. A probability value $p<0.05$ was considered significant.

\section{Conclusions}

This study shows that the direct testing of already isolated natural products is a valuable strategy to find new bioactivities. In this study, it enabled the identification of nonprenylated xanthones of high chemical stability as novel, non-toxic inhibitors of VSMC proliferation, which might be a starting point for the development of new therapeutic applications to combat restenosis.

Acknowledgments: This work was supported by the Austrian Science Fund (FWF): National Research Network (NFN) "Drugs from Nature Targeting Inflammation" (S10703 and S10704), P23317-B11, and P25971-B23, as well as the Standortagentur Tirol (TWF), the European Union Seventh Framework Program (EU-FP7) Marie Curie Fellowship 252881, and the University of Vienna "Back to Research Grant".

Author Contributions: B.W. selected natural products for the SAR study and drafted the manuscript; R.L. performed the experiments and analyzed data; S.S. and E.H. analyzed data and supported planning and interpretation of experiments; A.A., V.D., and H.S. conceived and supervised the study. All authors revised and approved the final manuscript.

Conflicts of Interest: The authors declare no conflict of interest.

\section{References}

1. Rader, D.J.; Daugherty, A. Translating molecular discoveries into new therapies for atherosclerosis. Nature 2008, 451, 904-913. [CrossRef] [PubMed]

2. Dzau, V.J.; Braun-Dullaeus, R.C.; Sedding, D.G. Vascular proliferation and atherosclerosis: New perspectives and therapeutic strategies. Nat. Med. 2002, 8, 1249-1256. [CrossRef] [PubMed]

3. Raja, S.G. Drug-eluting stents and the future of coronary artery bypass surgery: Facts and fiction. Ann. Thorac. Surg. 2006, 81, 1162-1171. [CrossRef] [PubMed]

4. Appendino, G.; Fontana, G.; Pollastro, F. 3.08-Natural products drug discovery. In Comprehensive Natural Products II; Liu, H.-W., Mander, L., Eds.; Elsevier: Oxford, UK, 2010; pp. 205-236.

5. Atanasov, A.G.; Waltenberger, B.; Pferschy-Wenzig, E.M.; Linder, T.; Wawrosch, C.; Uhrin, P.; Temml, V.; Wang, L.; Schwaiger, S.; Heiss, E.H.; et al. Discovery and resupply of pharmacologically active plant-derived natural products: A review. Biotechnol. Adv. 2015. [CrossRef] [PubMed]

6. Yang, X.P.; Pei, Z.H.; Ren, J. Making up or breaking up: The tortuous role of platelet-derived growth factor in vascular ageing. Clin. Exp. Pharmacol. Physiol. 2009, 36, 739-747. [CrossRef] [PubMed]

7. Hayashi, T.; Yamagishi, T. Two xanthone glycosides from Gentiana lutea. Phytochemistry 1988, 27, 3696-3699. [CrossRef]

8. Schmieder, A.; Schwaiger, S.; Csordas, A.; Backovic, A.; Messner, B.; Wick, G.; Stuppner, H.; Bernhard, D. Isogentisin-A novel compound for the prevention of smoking-caused endothelial injury. Atherosclerosis 2007, 194, 317-325. [CrossRef] [PubMed]

9. Kim, T.J.; Han, H.J.; Hong, S.S.; Hwang, J.H.; Hwang, B.Y.; Yoo, H.S.; Jin, Y.R.; Lee, J.J.; Yu, J.Y.; Lee, K.H.; et al. Cudratricusxanthone A isolated from the root bark of Cudrania tricuspidata inhibits the proliferation of vascular smooth muscle cells through the suppression of PDGF-receptor $\beta$ tyrosine kinase. Biol. Pharm. Bull. 2007, 30, 805-809. [CrossRef] [PubMed] 
10. Stout, G.H.; Balkenhol, W.J. Xanthones of the gentianaceae: I. Frasera caroliniensis Walt. Tetrahedron 1969, 25, 1947-1960. [CrossRef]

11. Shi, G.-F.; Lu, R.-H.; Yang, Y.-S.; Li, C.-L.; Yang, A.-M.; Cai, L.-X. Isolation and crystal structure of xanthones from Swertia chirayita. Chin. J. Struct. Chem. 2004, 23, 1164-1168.

12. Asthana, R.K.; Sharma, N.K.; Kulshreshtha, D.K.; Chatterjee, S.K. A xanthone from Swertia chirayita. Phytochemistry 1991, 30, 1037-1039. [CrossRef]

13. Aberham, A.; Pieri, V.; Croom, E.M., Jr.; Ellmerer, E.; Stuppner, H. Analysis of iridoids, secoiridoids and xanthones in Centaurium erythraea, Frasera caroliniensis and Gentiana lutea using LC-MS and RP-HPLC. J. Pharm. Biomed. Anal. 2011, 54, 517-525. [CrossRef] [PubMed]

14. Valentao, P.; Andrade, P.B.; Silva, E.; Vicente, A.; Santos, H.; Bastos, M.L.; Seabra, R.M. Methoxylated xanthones in the quality control of small centaury (Centaurium erythraea) flowering tops. J. Agric. Food Chem. 2002, 50, 460-463. [CrossRef] [PubMed]

15. Shi, G.-F.; Lu, R.-H.; Yang, Y.-S.; Li, C.-L.; Yang, A.-M.; Cai, L.-X. Crystal structure of 1,5,8-trihydroxyl-3-methoxy xanthone from Swertia chirayita. J. Chem. Crystallogr. 2005, 35, 135-139. [CrossRef]

16. Wolfender, J.-L.; Hamburger, M.; Msonthi, J.D.; Hostettmann, K. Xanthones from Chironia krebsii. Phytochemistry 1991, 30, 3625-3629. [CrossRef]

17. Ghosal, S.; Chaudhuri, R.K.; Nath, A. Chemical constituents of gentianaceae. IV. New xanthones of Canscora decussata. J. Pharm. Sci. 1973, 62, 137-139. [CrossRef] [PubMed]

18. Pinto, D.C.; Fuzzati, N.; Pazmino, X.C.; Hostettmann, K. Xanthone and antifungal constituents from Monnina obtusifolia. Phytochemistry 1994, 37, 875-878. [CrossRef]

19. Parra, M.; Picher, M.T.; Seoane, E.; Tortajada, A. New xanthones isolated from Centaurium linarifolium. J. Nat. Prod. 1984, 47, 123-126. [CrossRef]

20. Valentao, P.; Areias, F.; Amaral, J.; Andrade, P.; Seabra, R. Tetraoxygenated xanthones from Centaurium erythraea. Nat. Prod. Lett. 2000, 14, 319-323. [CrossRef]

21. Liu, R.; Heiss, E.H.; Sider, N.; Schinkovitz, A.; Groblacher, B.; Guo, D.; Bucar, F.; Bauer, R.; Dirsch, V.M.; Atanasov, A.G. Identification and characterization of [6]-shogaol from ginger as inhibitor of vascular smooth muscle cell proliferation. Mol. Nutr. Food Res. 2015, 59, 843-852. [CrossRef] [PubMed]

22. Sroka, I.M.; Heiss, E.H.; Havlicek, L.; Totzke, F.; Aristei, Y.; Pechan, P.; Kubbutat, M.H.; Strnad, M.; Dirsch, V.M. A novel roscovitine derivative potently induces $\mathrm{G}_{1}$-phase arrest in platelet-derived growth factor-BB-activated vascular smooth muscle cells. Mol. Pharmacol. 2010, 77, 255-261. [CrossRef] [PubMed]

23. Aberham, A.; Schwaiger, S.; Stuppner, H.; Ganzera, M. Quantitative analysis of iridoids, secoiridoids, xanthones and xanthone glycosides in Gentiana lutea L. roots by RP-HPLC and LC-MS. J. Pharm. Biomed. Anal. 2007, 45, 437-442. [CrossRef] [PubMed]

24. Kesavan, R.; Potunuru, U.R.; Nastasijevic, B.; Avaneesh, T.; Joksic, G.; Dixit, M. Inhibition of vascular smooth muscle cell proliferation by Gentiana lutea root extracts. PLoS ONE 2013, 8, e61393. [CrossRef] [PubMed]

25. Akileshwari, C.; Muthenna, P.; Nastasijevic, B.; Joksic, G.; Petrash, J.M.; Reddy, G.B. Inhibition of aldose reductase by Gentiana lutea extracts. Exp. Diabetes Res. 2012, 2012, 147965. [CrossRef] [PubMed]

26. Kušar, A.; Šircelj, H.; Baričevič, D. Determination of seco-iridoid and 4-pyrone compounds in hydro-alcoholic extracts of Gentiana lutea L. subsp. symphyandra Murb. leaves and roots by using high performance liquid chromatography. Isr. J. Plant Sci. 2010, 58, 291-296.

27. Kurin, E.; Atanasov, A.G.; Donath, O.; Heiss, E.H.; Dirsch, V.M.; Nagy, M. Synergy study of the inhibitory potential of red wine polyphenols on vascular smooth muscle cell proliferation. Planta Med. 2012, 78, 772-778. [CrossRef] [PubMed]

28. Joa, H.; Vogl, S.; Atanasov, A.G.; Zehl, M.; Nakel, T.; Fakhrudin, N.; Heiss, E.H.; Picker, P.; Urban, E.; Wawrosch, C.; et al. Identification of ostruthin from Peucedanum ostruthium rhizomes as an inhibitor of vascular smooth muscle cell proliferation. J. Nat. Prod. 2011, 74, 1513-1516. [CrossRef] [PubMed]

29. Blazevic, T.; Schwaiberger, A.V.; Schreiner, C.E.; Schachner, D.; Schaible, A.M.; Grojer, C.S.; Atanasov, A.G.; Werz, O.; Dirsch, V.M.; Heiss, E.H. 12/15-Lipoxygenase contributes to platelet-derived growth factor-induced activation of signal transducer and activator of transcription 3. J. Biol. Chem. 2013, 288, 35592-35603. [CrossRef] [PubMed] 
30. Schwaiberger, A.V.; Heiss, E.H.; Cabaravdic, M.; Oberan, T.; Zaujec, J.; Schachner, D.; Uhrin, P.; Atanasov, A.G.; Breuss, J.M.; Binder, B.R.; et al. Indirubin-3'-monoxime blocks vascular smooth muscle cell proliferation by inhibition of signal transducer and activator of transcription 3 signaling and reduces neointima formation in vivo. Arterioscler. Thromb. Vasc. Biol. 2010, 30, 2475-2481. [CrossRef] [PubMed]

31. Sepp, A.; Binns, R.M.; Lechler, R.I. Improved protocol for colorimetric detection of complement-mediated cytotoxicity based on the measurement of cytoplasmic lactate dehydrogenase activity. J. Immunol. Methods 1996, 196, 175-180. [CrossRef]

32. Fakhrudin, N.; Waltenberger, B.; Cabaravdic, M.; Atanasov, A.G.; Malainer, C.; Schachner, D.; Heiss, E.H.; Liu, R.; Noha, S.M.; Grzywacz, A.M.; et al. Identification of plumericin as a potent new inhibitor of the NF-kB pathway with anti-inflammatory activity in vitro and in vivo. Br. J. Pharmacol. 2014, 171, 1676-1686. [CrossRef] [PubMed]

Sample Availability: Not available.

(C) 2015 by the authors; licensee MDPI, Basel, Switzerland. This article is an open access article distributed under the terms and conditions of the Creative Commons by Attribution (CC-BY) license (http://creativecommons.org/licenses/by/4.0/). 